\title{
Features of the introduction of representatives of the genus Inula $L$.
}

\author{
Vladimir Sorokopudov ${ }^{1}$, Alexander Kabanov², and Ibragim Bamatov ${ }^{3, *}$ \\ ${ }^{1}$ Russian State Agrarian University - Moscow Timiryazev Agricultural Academy, 49, Timiryazevskaya street, Moscow, 127550 , \\ Russian Federation \\ ${ }^{2}$ Tsytsin Main Botanical Garden of Russian Academy of Science, Moscow, Russian Federation \\ ${ }^{3}$ FGBNU FIC "V. V. Dokuchaev Soil Science Institute” Pyzhevsky lane, 7s2, Moscow, 119017, Russia
}

\begin{abstract}
Representatives of the genus Inula are promising for introduction due to their wide range of uses. So, many species are ornamental plants, promising for introduction, including in urban landscaping. Several species are medicinal plants, and even though recently the chemical composition of certain species of this genus has been studied, it was evident that this work must be continued to maximize the study of the possibilities of this genus. The article discusses the experience of introducing representatives of the genus Inula in the Main Botanical Garden named after N.V. Tsitsin RAS in the aspect of general introduction work both in the gardens of the former USSR, Western Europe, and the USA. The fact states that only natural species found in the natural flora of the USSR prevailed in the botanical gardens of the countries of the former USSR. At the same time, East Asian and Iranian-Turanian species are representatively represents in foreign botanical gardens. For the Russian flora and neighboring countries (within the borders of the former USSR), 33 species have been recorded, of which 15 species have undergone an introduction study at the Russian Academy Science (RAS). For all species studied at the GBS RAS, the flowering time in the conditions of central Russia was analyzed, the possibilities of using it both for decorative and other purposes were indicated. According to literary sources, the analysis of the component composition of raw materials of 16 natural species found within this region was carried out.
\end{abstract}

Keywords: cultural flora, genera complex, introduction, decorative properties, medicinal plant, representatives of the genus Inula $\mathrm{L}$.

\section{Introduction}

The expansion of the cultural flora through the introduction of natural species into its composition is the main direction of the activity of botanical gardens. At the same time, an important task is to select the most promising plants with high decorative qualities, medicinal or technical properties. Such a valuable complex of characters characterizes representatives of the genus Inula L. The main purpose of this work is to summarize the results of the introduction of various species of this genus into the cultural flora.

Natural species of the genus Inula L. are interested not only as a source of medicinal raw materials but also as quite ornamental plants promising for introduction studies. According to various sources, the volume of this genus ranges from 90 (Coombes, 2009) to 100 natural species found in Asia, Africa, and Europe (Coombes, 2012). Particular attention in the article has apeared to the species of the genus Inula, found in the territory of the former USSR. The interest reason of scientists explained by the species diversity, and the introduction knowledge (Floral-decorative herbaceous plants, 1983; Catalog of floral-decorative herbaceous plants of the botanical gardens of the CIS and Baltic countries, 1997 ; Mironova et al., 2006; Plants of natural flora in the Main Botanical Garden named after N.V. Tsitsin, 2013).

In the natural flora of Russia and neighboring states (within the former USSR), 33 species were recorded (Flora SSSR, 1959). Moreover, the geographical distribution of this genus is of particular interest. Thus, there are 3 separate centers with the maximum species diversity - the Caucasus, Central Asia and the Far East. In general, for Central Asia, the maximum species diversity is noted, so of the 16 species found here - 10 species are characteristic only for this region, and of them - 6 are endemic. Central Asian species are mountain plants, the introduction of which, especially endemic species, is difficult in the conditions of central Russia. Caucasian species of this genus are also interesting. Therefore, for the Caucasus flore, 13 species have been identified, of which 6 are mostly found only in this region. Ecologically, the group of Caucasian species is more diverse - in addition to mountain slopes, some species are also characteristic of meadow (alpine and subalpine), steppe and forest communities. Potentially, these species, except the Transcaucasian species, characterized by more

\footnotetext{
* Corresponding author: ibragim-1991@mail.ru
} 
xerophilic growing conditions, are promising for introduction in Central Russia. The Far Eastern group is represented by 3 species associated with forest and meadow communities.

Simultaneously, no purely European and Siberian species for this genus have been identified in the flora of the former USSR. 11 species characterized by a wide range. The main feature of such species is a wide reaction rate and prospects for introduction work. The most common are only two species - Inula salicina L. and Inula britannica L. are found in a wide strip covering Europe, Siberia (Western and Eastern), partly - Central Asia and the Far East.

As already noted above, when introducing plants, it is important not only to assess the resistance of a particular species to ecological and climatic conditions, but also to identify valuable economic qualities of plants decorativeness, the possibility of using them in medicine and other spheres of economic activity. The decorativeness of individual species of this genus confirms by numerous works (Catalog of Plants of the Donetsk Botanical Garden, 1988; Catalog of Plants of the Central Botanical Garden, 1997, etc.). But perhaps the most important is that some species of this genus are valuable plants from a medical point of view. Despite numerous studies of several species of this genus (Stojakowska et al. 2010; Nie et al. 2010; Degerli et. al., 2012; Olennikov and Tankhaeva, 2012), not all natural species are included in the studies.

\section{Results and Discussions}

The most common species in the cultivated flora is I. helenium L., a medicinal and ornamental plant introduced into cultivation in antiquity (Poletiko and Mishenkova, 1967). Also, five more species have been cultivated as ornamental for a long time - I. ensifolia L. (cultivated since 1793), I. Grandiflora Willd. (since 1804 in the Botanical Garden of Peter the Great, St. Petersburg), I. hirta L. (since 1804) and I. royleana DC. (since 1897) (Poletiko, Mishenkova, 1967). There are about 28 natural species and four varieties in the cultural flora (Catalog of floral and ornamental herbaceous plants, 1997; Herbaceous ornamental perennials of the Main Botanical Garden, 2009; Philip, Lord, 2012, etc.) It should be noted that when comparing the list of species of the genus Inula that have passed the introduction test and entered the cultural flora, the set of species differs significantly between the countries of the former USSR and the collections of botanical institutions of Western Europe and the USA. Almost all volume of species (16 - in the cultural flora of Western Europe and the USA and 20 - in the cultural flora of the former USSR), only seven species coincide, which are the most common in culture and have a high decorative effect: Inula ensifolia, I. helenium, I. hirta, I. orientalis Lam., I. racemosa Hook. f., I. royleana, I. salicina L. Botanical institutions in Western Europe and the United States characterizes by a set of species that have not undergone an introduction study at the RAS: I. acaulis Schott \& Kotschy ex Boiss., I. afghanica Rech. f. \& Köie (synonym - Pentanema glanduligerum (Krasch.)
Gorschk.), I. barbata Wall. (in some cases it is considered a synonym for I. orientalis), I. conyzae (Griess.) Meikle, I. cordata Boiss (in some cases it is considered a synonym for I. aspera), I. dysenterica L., I. glandulosa Lam. (syn. Chrysopsis mariana (L.) Elliott), I. hookeri C.B. Clarke, I. macrocephala Boiss. \& Kotschy ex Boiss. (Philip, Lord, 2012).

In the Main Botanical Garden of the Russian Academy of Sciences (MGB RAS), an introductory study of 17 natural species and one cultivar of this genus was carried out - I. Aspera Poir., I. Britannica L., I. ensifolia L., I. helenium L., I. hirta L., I. japonica Thunb., I. Magnifica Lipsky, I. Mariae Bordz., I. oculis-Christi L., I. Orientalis Lam., I. racemosa, I. rhizocephala Schrenk, I. royleana DC., I. salicina L., I . thapsoides (Willd.) Spreng. (Plants of the natural flora of the USSR, 1961; Herbaceous ornamental perennials of the Main Botanical Garden, 2009; Plants of natural flora in the Main Botanical Garden, 2013). The collection is dominated by species belonging to the natural flora of the former USSR, and this is due to the specifics of the formation of the collection fund at that time. Later, the collection fund included species not found in the natural flora of the former USSR - Himalayan species - I. racemosa and I. royleana.

The introduction study of representatives of the genus Inula in the Main Botanical Garden of the Russian Academy of Sciences accords to the standard two-stage technique, which includes the stage of the primary introduction study, after receiving the preliminary information about the prospects of introducing the studied samples into the culture, the second stage of the introduction studies is carried out. The genus Inula's collection fund is formed based on two methods: generic complexes and ecological-phytocenotic. In the Laboratory of Ornamental Plants of the MBG RAS, species of the genus Inula were collected and studied within the framework of generic complexes proposed by F.N. Rusanov (1950). A feature of this introduction method is the broadest possible attraction of both biological species and varieties that are grown at the identical exposition, which makes it possible to identify the most stable, highly decorative, and promising samples for introduction into the cultural flora of the region. Despite the apparent advantages, the Rusanov method also has some disadvantages. Thus, depending on the soil and climatic conditions of the point of introduction, this approach has several limitations, which often prevent the introduction of a significant number of representatives of a particular botanical taxon. Thus, it is not acceptable for genera in which species with different ecological preferences are represented. However, individual representatives of the genus Inula included in the modern collection fund do not require specific growing conditions, and in general, this method has shown its effectiveness in assessing the introduction prospects of this genus. The second method of introduction, used at MBG RAS in the Laboratory of Natural Flora, is ecological-phytocenotic (Trulevich, 1991). This methods based on the formation of collections of plants characterized by different taxonomic affiliations but having a common ecology - plants of forests, steppes, 
scree, etc. This method allows you to grow introduced plants in the most comfortable conditions for them.

In addition to these species, the following species of elecampane were introduced in the botanical gardens of the former USSR - I. germanica L., I. Grandiflora, I. macrophylla Kar. et Kir.

Among the species that have passed the introduction test at the GBS RAS, the most decorative and promising introduction into mass urban landscaping are the following species: - I. Magnifica, I. racemosa, I. royleana, I. Grandiflora. For compositions imitating natural communities, it is promising to use such species as I. helenium, I. Britannica, I. ensifolia. Almost all species, except for I. Mariae (a biological species from Transcaucasia, which characterized by a narrow reaction rate, did not bloom under the conditions of Moscow and was unstable in culture) are stable under cultural conditions, form seeds annually, in some cases mass selfseeding is possible (I. helenium, I. salicina).

When analyzing the flowering times of various types of elecampane in the collection fund of the GBS RAS, three groups can be distinguished by flowering time:

Group 1 - early flowering (June - July) - I. Aspera, I. Britannica (flowering from June to August), I. ensifolia, I. Magnifica, I. Orientalis, I. rhizocephala;

Group 2 - blooming in medium terms (in July August) - I. helenium, I. oculis-Christi, I. rhizocephala, I. royleana, I. salicina;

Group 3 - late-blooming (August-September) - I. japonica, I. racemosa, I. thapsoides. It should be noted that representatives of the third group are the most interesting for introduction into urban gardening due to the relatively late flowering period.

Among the species tested in the introduction experiment, representatives of meadow and subalpine communities predominate. Long-term introduction tests conclude that further introduction testing of new species from these communities may be promising. Rocky species are less resistant and require particular soil and climatic conditions; they are often not long-lived in culture.

As mentioned above, in addition to decorative properties, several elecampane species have other valuable qualities. Thus, Inula helenium possesses medicinal and nutritional valuable traits and the possibility of using it as natural insecticides and dyeing properties (Pashina and Kukhareva, 1986). Inula macrophylla - medicinal, technical, and melliferous plant; I. salicina has medicinal properties, and I. Aspera is a melliferous plant, which also has fodder value. Britannica - medicinal, fodder, and melliferous plant; I. hirta is a medicinal plant. Other types of elecampane also have medicinal properties: I. Conyza DC., I. germanica, I. ensifolia, I. Magnifica (Solodko et al., 2006).

The study of the chemical composition of representatives of the genus Inula has been carried out for a long time. However, it is in recent years that there has been an increase in interest in research on the study of biologically active substances of plant origin, including in representatives of the genus Inula (Zang H., et al., 2009; Yang Y. et al., 2011;). The results obtained indicate a wide range of valuable biologically active substances that are widely used in medicine. For 16 natural species growing on the territory of Russia and the countries of the former USSR, based on a number of sources (Zang H., et al., 2009; Budantsev, 2013; Stojakowska et al., 2010; Nie et al., 2010; Yang Y. et al., 2011; Degerli et al., 2012; Olennikov, Tankhaeva, 2012, etc.), an analysis of biologically active substances was carried out (Table 1).

Table 1. Biologically active substances in representatives of the genus Inula

\begin{tabular}{|c|c|c|c|c|c|c|c|c|c|c|c|c|c|c|c|c|}
\hline $\begin{array}{l}\text { Species } \\
/ / \\
\text { Biologi } \\
\text { cally } \\
\text { active } \\
\text { substan } \\
\text { ces }\end{array}$ & $\begin{array}{l}\text { Inul } \\
\text { a } \\
\text { brit } \\
\text { anni } \\
\text { ca } \\
\text { L. }\end{array}$ & $\begin{array}{l}\text { Inu } \\
\text { la } \\
\text { cas } \\
\text { pic } \\
\text { a } \\
\text { F. } \\
\text { K. } \\
\text { Bl } \\
\text { um } \\
\text { ex } \\
\text { Le } \\
\text { de } \\
\text { b. }\end{array}$ & $\begin{array}{l}\text { In } \\
\text { ula } \\
\text { co } \\
\text { ny } \\
\text { za } \\
\text { D } \\
\text { C. }\end{array}$ & $\begin{array}{l}\text { Inu } \\
\text { la } \\
\text { ens } \\
\text { ifol } \\
\text { ia } \\
\text { L. }\end{array}$ & $\begin{array}{l}\text { Inul } \\
\text { a } \\
\text { ger } \\
\text { man } \\
\text { ica } \\
\text { L. }\end{array}$ & $\begin{array}{l}\text { Inul } \\
\text { a } \\
\text { hel } \\
\text { eni } \\
\text { um } \\
\text { L. }\end{array}$ & $\begin{array}{l}\text { Inu } \\
\text { la } \\
\text { jap } \\
\text { oni } \\
\text { ca } \\
\text { Th } \\
\text { un } \\
\text { b. }\end{array}$ & $\begin{array}{l}\text { Inul } \\
\text { a } \\
\text { linar } \\
\text { iifol } \\
\text { ia } \\
\text { Tur } \\
\text { cz. }\end{array}$ & $\begin{array}{l}\text { Inula } \\
\text { macr } \\
\text { ophy } \\
\text { lla } \\
\text { Kar. } \\
\text { et } \\
\text { Kir. }\end{array}$ & $\begin{array}{l}\text { Inul } \\
\text { a } \\
\text { mag } \\
\text { nifi } \\
\text { ca } \\
\text { Lip } \\
\text { sky }\end{array}$ & $\begin{array}{l}\text { In } \\
\text { ul } \\
\text { a } \\
\text { oc } \\
\text { uli } \\
\text { s- } \\
\text { ch } \\
\text { ris } \\
\text { ti } \\
\text { L. }\end{array}$ & $\begin{array}{l}\text { Inul } \\
\text { a } \\
\text { rac } \\
\text { em } \\
\text { osa } \\
\text { Ho } \\
\text { ok.f }\end{array}$ & $\begin{array}{l}\text { Inula } \\
\text { rhizo } \\
\text { ceph } \\
\text { ala } \\
\text { Schr } \\
\text { enk }\end{array}$ & $\begin{array}{l}\text { Inu } \\
\text { la } \\
\text { roy } \\
\text { lea } \\
\text { na } \\
\text { DC } \\
\text {. }\end{array}$ & $\begin{array}{l}\text { Inu } \\
\text { la } \\
\text { sal } \\
\text { ici } \\
\text { na } \\
\text { L. }\end{array}$ & $\begin{array}{l}\text { Inul } \\
\text { a } \\
\text { thap } \\
\text { soid } \\
\text { es } \\
\text { (Bie } \\
\text { b.) } \\
\text { Spre } \\
\text { ng. }\end{array}$ \\
\hline \multirow[t]{2}{*}{$\begin{array}{l}\text { Alantol } \\
\text { actone }\end{array}$} & & & & & & + & & & + & + & & + & & & + & \\
\hline & & & & & & + & & & & & & & & & & \\
\hline \multirow[t]{2}{*}{$\begin{array}{l}\text { Benzoic } \\
\text { acid }\end{array}$} & + & + & & & & & & + & & & & & & & & \\
\hline & + & & & & & & & & & & & & & & & \\
\hline Briton & & & & & & + & & & & & & & & & & \\
\hline $\begin{array}{l}\text { Vanilla } \\
\text { acid }\end{array}$ & + & & & & & & & & & & + & & & & & \\
\hline
\end{tabular}




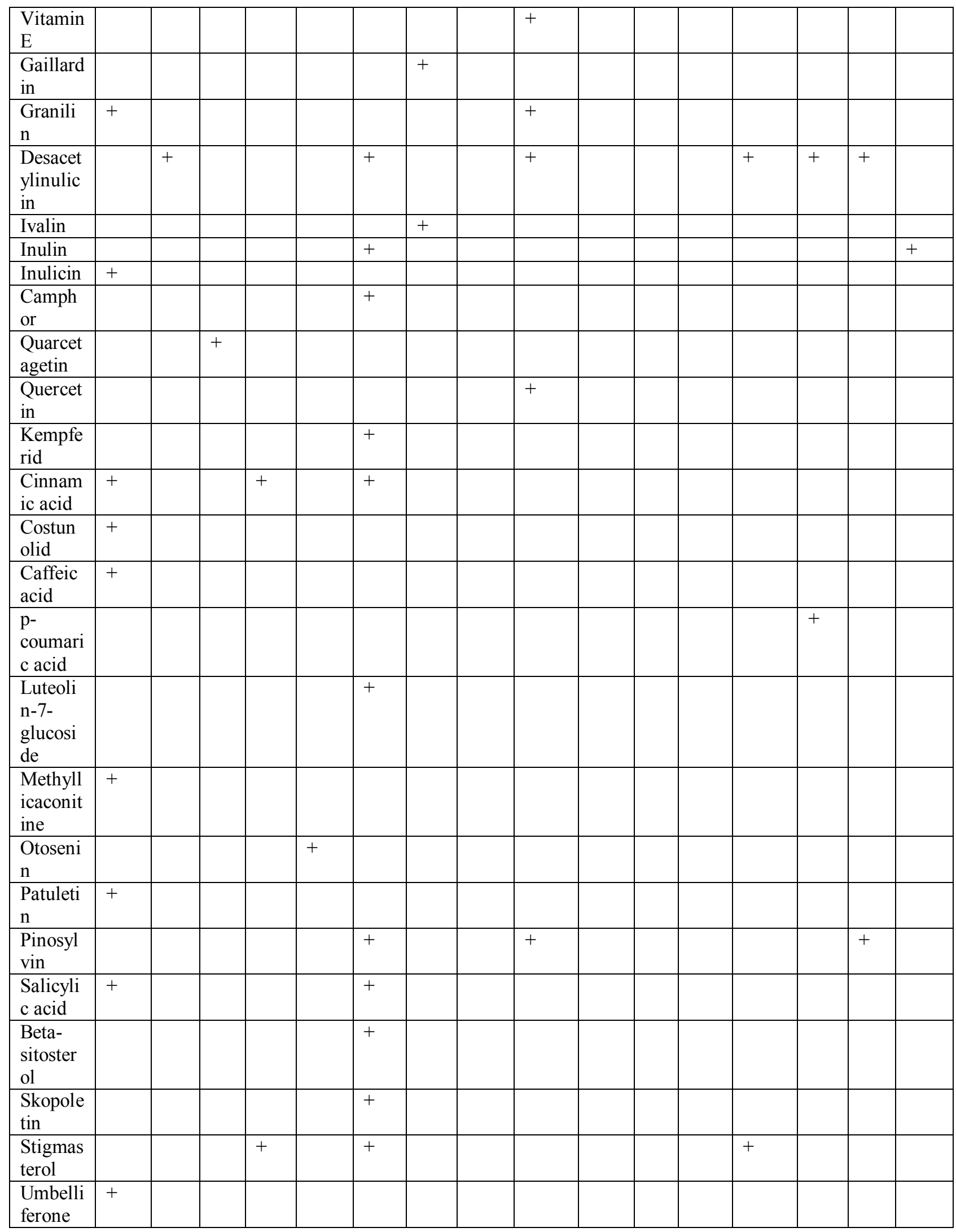

When analyzing literary sources, among the identified biologically active substances, a set of 27 substances should be especially distinguished:

1. alantolactone (alantolactone) - anthelmintic, antiseptic, diuretic, expectorant, antitumor;
2. benzoic acid (benzoic acid) - bactericidal, fungicidal, expectorant, poisonous (in contact with the skin);

3. British (britannin) - protistocidal, bactericidal, fungicidal, antitumor;

4. vanillic acid - anthelmintic; 
5. gaillardin (gaillardin) - protistocidal, cytotoxic, bactericidal, fungicidal;

6. vitamin E (vitamin E) - is actively used in medicine, antioxidant, etc.;

7. granilin (granilin) - antibiotic, fungicidal, bactericidal;

8. desacetilinulicin (desacethylinulicin) bactericidal, fungicidal;

9. ivalin (ivalin) - antineoplastic; inulin (inulin) dietary;

10. inulicin (inulicin) - bactericidal, fungicidal; camphor (camphor) - antiseptic, antispasmodic, antiinflammatory, stimulating;

11. Quartztagetin (quarcetagetin) - antioxidant; quercetin (quercitin) (quercetin, quercitin) - is actively used in medicine;

12. kaempferide (kaempferide) - antineoplastic;

13. costunolide - antineoplastic;

14. cinnamic acid (chinnamic acid) - antispasmodic, bacteriostatic;

15. caffeic acid - bacteriostatic, choleretic;

16. p-coumaric acid (p-coumaric acid) antihepatotoxic;

17. luteolin-7-glucoside (luteolin-7-glucosid) - antiinflammatory, choleretic, capillary-strengthening;

18. methyllycaconitine - is actively used in medicine;

19. othosenin - antispasmodic;

20. patuletin (patuletin) - antispasmodic;

21. pinosylvin (pinosylvin) - bactericidal, fungicidal;

22. salicylic acid (salicyclic acid) - bactericidal, analgesic, anti-inflammatory;

23. beta-sitosterol (beta-sitosterol) - estrogenic, antitumor, fungicidal, bacteriostatic;

24. scopoletin (scopoletin) - antitumor, antispasmodic, hypoglycemic;

25. stigmasterin (stigmasterin) - antineoplastic;

26. umbelliferone (umbelliferone) - fungicidal, bactericidal, antispasmodic;

27. chlorogenic acid - choleretic; eupapholin (eupapholin) - bactericidal.

As can be seen from the list of chemicals, the plant material obtained from various Inula species dominates fungicidal and bactericidal substances. There are also many substances with antitumor effects (8 substances). It follows from the table that the most considerable number of identified biologically active substances obtains in three species - Inula helenium (12), Inula Britannica (10), and Inula macrophylla (5). The remaining species are characterized by a small number $(1-2)$ of the identified biologically active substances. When analyzing the occurrence of various substances in various representatives of the genus Inula, only two substances were found to be widespread - inulin (noted in 6 species) and alantolactone (in 5 species). Less common are British, caffeic acid, and beta-sitosterol (in 3 species). The rest of the substances are rarer and only in certain species.

\section{Conclusion}

Some representatives of the genus Inula have long been included in the world cultural flora. However, the introduction potential of this genus continues to remain relatively high. Obviously, at present, the most promising is the study of the East Asian species of this genus growing in the highlands of China and India. The species of the Caucasus and Asia Minor are also insufficiently studied. As noted above, when introducing several Central Asian species, difficulties arise due to the discrepancy between the soil and climatic conditions of the introduction point with the initial conditions of the distribution region. However, this region is characterized by a high level of endemism. The increasing anthropogenic impact necessitates the preservation of this group and its introduction into the collection funds of the world's botanical gardens.

Another promising direction is the conduct of complex research, including studying the composition of biologically active substances in plant raw materials. This work is promising for both new species in the introduction, and long-term tested species. It is difficult, but potentially significant, to compare changes in the chemical composition of raw materials obtained from the same species with a wide range, but when studying samples growing in different points of the range and under different environmental conditions.

\section{Acknowledgment}

This work was carried out within the framework of the State Task Main Botanic Garden Russian Academic Science (№118021490111-5).

\section{Reference}

1. Biological resources of Russia: Wild flowering plants, their component composition and biological activity. T.5. Family Asteraceae (Compositae). Part 2. Childbirth Echinops - Youngia (KMK Scientific Publishing Partnership, Saint Petersburg, Moscow, 2013)

2. L.R. Azarkh, V.V. Bakanova, R.I. Burda and etc. Catalog of plants of the Donetsk Botanical Garden: Reference Manual (Naukova Dumka, Kiev, 1988)

3. Catalog of plants of the Central Botanical Garden. N.N. Grishko (Naukova Dumka, Kiev, 1997)

4. L.V. Kukhareva, G.V. Pashina Useful herbaceous plants of natural flora: a guide based on the results of introduction in Belarus (Nauka i tekhnika, Minsk, 1986)

5. L.N. Mironova, A.A. Vorontsova, G.V. Shipaeva Results of the introduction and selection of ornamental herbaceous plants in the Republic of Bashkortostan. Part 2. (Nauka, Moscow, 2006)

6. O.M. Poletiko, A.P. Mishenkova Ornamental herbaceous plants in open ground (Nauka, Leningrad, 1967) 
7. Plants of natural flora in the Main Botanical Garden. N.V. Tsitsina of the Russian Academy of Sciences: 65 years of introduction (Nauka, Moscow, 2013)

8. F.N. Rusanov Bull. of the Main Bot. Gard. New methods of plant introduction 7(27) (1950)

9. A.S. Solodko, M.V Nagalevsky., P.V. Kiriy Atlas of the flora of the Sochi Black Sea region. Wild vascular plants (Sochi, 2006)

10. Herbaceous decorative perennials of the Main Botanical Garden. N.V. Tsitsina RAS: 60 years of introduction (Nauka, Moscow, 2009)

11. N.V. Trulevich Ecological and phytocenotic foundations of plant introduction (Nauka, Moscow, 1991)

12. Flora of the USSR 25 (Publishing house of the Academy of Sciences of the USSR, MoscowLeningrad, 1959)

13. Floral and decorative herbaceous plants (brief summary of the introduction) (Nauka, Moscow, 1983)

14. A. Coombes Dictionary of Plant Names. Timber Press (2009)

15. A. Coombes The A to Z of Plant Names. Timber Press (2012)

16. S. Degerli, S. Berk, E. Malatyali, B. Tepe Parasitol. Res. Screening of the in vitro amoebicidal activities of Pastinaca armenea (Fisch. Et. CA Mey.) And Inula oculis-christi (L.) on Acanthamoeba castellanii cyst and trophozoites 110(2) (2012)

17. L.-Y. Nie, J.-J. Qin, Y. Huang, L. Yan, Y.-B. Liu, Y.X. Pan, H.-X. Jin, W.-D. Zhang. J. Nat. Prod. Sesquiterpenoids from Inula lineariifolia inhibit nitric oxide production 73(6) (2010)

18. D.N Olennikov., L.M. Tankhaeva Chem. Nat. Compd. Phenylpropanoids from subterranean organs of Inula helenium 48(2) (2012)

19. C. Philip, T. Lord RHS Plant Finder 2012 - 2013. The Royal Horticultural Society (2012)

20. A. Stojakowska, J. Malarz, S. Zubek, K. Turnau, W. Kisiel Biochem. Syst. Ecol. Terpenoids and phenolics from Inula ensofolia 38(2) (2010)

21. J.-L. Yang, R. Wang, L.-L. Liu, Y.-P. Shi Planta Med. Sesquiterpenoids from Inula Britannica 77(4) (2011)

22. H.B. Zang, J.K. Wen, Y.Y. Wang, B. Zeng, M. Han. J. Etnopharmacol Flavonoids from Inula Britannica L. inhibit injury-induced neointimal formation by suppressing oxidative-stress generation 126(1) (2009) 